\title{
A Livelihood Perspective on Natural Resource Management and Environmental Change in Semiarid Tanzania*
}

\author{
Torben Birch-Thomsen \\ Institute of Geography, University of Copenhagen, \\ Copenhagen, Denmark \\ tbt@geogr.ku.dk \\ Pia Frederiksen \\ Department of Policy Analysis, \\ National Environmental Research Institute, \\ Roskilde, Denmark \\ pfr@dmu.dk \\ Hans-Otto Sano \\ Danish Centre for Human Rights, Copenhagen \\ hos@humanrights.dk
}

\begin{abstract}
The aim of this paper is to explore how social relations influence land use and natural resource management at the local level. Through empirical analysis that tracks changes in land use and environment over 40 years, we present evidence of a process of agrarianization based on commercialization of crops and expansion of cultivated land. With the concept of livelihood strategies as an analytical framework, subcommunity processes are analyzed for their impact on intensification and degradation. Accumulating strategies are linked to expansion, commercial crop production, and selective intensification through high-value inputs, while at the other end of the scale, peasant-labor households endure exhausted or marginal potential land resources combined with lack of flexibility in input consumption. The article shows how degradation and intensification occur simultaneously and how incomes may increase even during processes of land degradation. We argue that a livelihood approach can be useful in uncovering and explaining these processes.
\end{abstract}

Key words: livelihood strategies, environmental change, land degradation, land use intensification, Tanzania.

This article is about environmental change and livelihood strategies. It seeks to explore how social relations and strategies can influence environmental change, but

* All authors are members of the SASA research program (Sustainable Agriculture in Semi-arid Africa), a research cooperation between the Centre for Development Research, Copenhagen; Institute of Geography and International Development Studies, University of Roskilde; Institute of Geography, University of Copenhagen; and Royal School of Veterinary and Agricultural Studies, also how livelihood diversification may be seen as part of a strategy to retain access to or control over land. The purpose is partly methodological, in the sense that the concept and application of a livelihood approach are examined.

\footnotetext{
Copenhagen; in collaboration with Institute of Resource Assessment, University of Dar es Salaam. The case village studied here was one of six investigated by an interdisciplinary SASA research team. A draft version of this paper was originally presented at the IUAES/IGU Congress on "Livelihoods from Resource Flows” in Linköping, 19-22 August 1996.
} 
The context is a semiarid area in Tanzania, where land use and environmental change over the last 40 years are described. A case study methodology has been applied, with the village of Ikuwala forming the central background against which environmental and social change are discussed. Ikuwala is located in Iringa District, approximately 500 kilometers southwest of the capital of Dar es Salaam. It is a subvillage under the greater village of Ilula, a commercially lively community located on the Iringa-Dar es Salaam highway. Ikuwala benefits from its proximity to the road. Since the early 1980s, tomato cultivation has become a major source of income in Ikuwala as well as in other localities close to the road.

The interest in livelihood strategies derives partly from the interdisciplinary integration between social and natural science perspectives. Complexity and diversity of change and a growing emphasis on local knowledge have brought social and natural science together in new institutional frameworks of research. One important outcome of this integration is the effort to develop interdisciplinary methods, while another is a growing sensitivity to local diversity. Such insights and endeavors have inspired the approach we have taken in the present article and its analysis of change as seen from below. While many studies of environmental change in Tanzania have been conducted with their point of departure in the nature of land use change and possible degradation, ${ }^{1}$ these processes are still so rudimentarily understood that case study methodologies are warranted. One important finding from the study described here is that intensification,

\footnotetext{
${ }^{1}$ Land degradation and desertification have been discussed at length (see, e.g., Dahlberg (1994) and Little (1994) for summaries), and the dynamics of vegetation succession and change in drylands have been debated in arguments against the concepts of stability and equilibrium as characteristics of dryland ecosystems (Ellis and Swift 1988; Thomas and Middleton 1994, 128).
}

conservation, and degradation occur simultaneously. Such processes are, we argue, strongly dependent on the nature and development of diverse livelihood strategies at the subcommunity level.

\section{Environmental Change and Livelihood Strategies}

Stagnation in agriculture due to humaninduced land degradation has been the subject of debate for several decades, especially concerning semiarid parts of subSaharan Africa. Earlier research efforts were devoted to the definition of processes of degradation and desertification, and explanations were found mainly in poor management regimes leading to overgrazing, overcultivation, and deforestation. Research in the last two decades, however, has demonstrated that technicist and management-oriented explanations are inadequate, not least in explaining the diversity of change and in attributing sufficient importance to social and political factors, both at the micro and the macro levels (Dahlberg 1994).

A growing integration of natural and social science perspectives has resulted in explanations that are both less categoric in defining environmental change as degradation and less conclusive in attributing environmental problems to people and communities (Thomas and Middleton 1994; Dahlberg 1994; Little 1994; Fairhead and Leach 1996). During the 1980s and 1990s, the social science perspective contributed to moving part of the explanation of degradation from peasants and pastoralists to either the character of political economy (Blaikie 1985; Blaikie and Brookfield 1987), the form of state intervention (Thomson 1994), or the institutions governing natural resource management (Secher Marcussen 1993). Thus, not only has the perspective on the nature of environmental change been altered, but causation and policy intervention issues have been reassessed. From the concern with technical solutions and with restructuring 
herd sizes, production techniques, and inputs at the community level that prevailed during the 1970 s, the debate about interventions and/or remedies now revolves to a much larger degree around the complexity of local and wider community interactions - whether the point of departure is taken from above, in areas such as market liberalization, or from below, in reinterpreting local change. ${ }^{2}$

While local change and diversity and indigenous knowledge are increasingly emphasized, the "local" discourse often remains at the level of the community, as for instance in the Boserupian reinterpretation of conservation and intensification processes in West and East Africa (Netting 1993; Tiffen, Mortimore, and Gichuki 1994; Mortimore 1995). Subcommunity processes such as social differentiation, growing poverty, and a diversity of livelihood strategies, however, render such generalized community-level interpretations insufficient for understanding how processes of natural resource conservation are sustained from below. In fact, conservation success stories are often written with a strong focus on the outcome of success, while less attention is paid to the stories of loss, marginalization, and poverty in the process. It is our conviction that, due to heterogeneity within the rural communities in terms of access to and control over resources, conservation and degradation may take place simultaneously within a smallholder community owing to the diversity of household strategies.

The livelihood perspective as a way of studying change from below and as a way of emphasizing actor diversity has recently gained importance. One example is when

\footnotetext{
${ }^{2}$ In Tanzania, much of the literature dealing with environmental change has been conducted "from above," with the point of departure in marketing reforms. See Bagachwa and Limbu (1995), Reed (1996), Aune (1997), Øygård (1997). Studies of environmental change with a bottom-up perspective are found in Östberg (1995) and Loiske (1995).
}

the United Nations Development Programme (UNDP), toward the end of the 1990s, made "sustainable livelihoods" a focus area for poverty reduction (UNDP 1999), another when the British Department for International Development (DFID) in 1998 redefined its approach to rural development as "sustainable rural livelihoods" (Carney 1998; see also Bryceson 1999). The interest in livelihoods derives from many quarters: from studies of coping in arid and semiarid environments (Reitsma, Dietz, and Haan 1992; Davies 1996), from studies emphasizing income diversification in rural communities (Preston 1992; Reardon 1997; Ellis 1998; Bryceson 1999), from studies of poverty and environmental degradation (Reardon and Vosti 1995; Murton 1997; Scoones 1998; Bebbington 1999), and finally from studies of changing gender roles (Joekes et al. 1994; Francis 1998). UNDP draws on the approaches developed in institutions like the Institute of Development Studies and the International Institute for Sustainable Development (UNDP 1999).

A key notion that has been central in many of the previous discussions of livelihoods is that of rural diversity, and with that, an emphasis on the importance of nonagricultural income sources in constituting rural livelihoods (see, for instance, Ellis 1998). Use and management of natural resources, moreover, is increasingly linked to broadly conceived resource access (Bebbington 1999). Studies of natural resource management could therefore benefit from moving the focus from agrarian livelihoods and farming systems to rural livelihoods, incorporating the whole resource endowment.

A point of departure in our effort to elaborate on livelihood strategies, however, is an understanding of livelihoods as an approach to the study of rural change and environmental management. Three dimensions are inherent in this approach: first, the provision of a framework whereby it becomes possible to examine how wider socioeconomic and sociopolitical change 
relates to local change; second, an emphasis on the importance of social differentiation and of agency in determining outcomes of local change; and third, the importance lent to both physical and social resources employed by individuals or households in shaping strategies and values for living. Thus, the livelihood study at the core level examines household or individual access to, utilization of, and allocation of resources, while at the secondary level it focuses on how local livelihood strategies interact with wider changes in markets and political institutions and with environmental and social conditions.

The aim of this article is thus to elaborate empirically on livelihood and environmental change in order to explore how conservation and intensification ${ }^{3}$ practices are socially related. A secondary purpose is to throw light on the relative importance of agricultural incomes in this particular local setting of Ikuwala, where diversification occurs as a strategy of defending access to and control over land even by the poorest groups.

A historical perspective is warranted (see also Scoones 1997). Longitudinal studies of livelihood remain difficult, however, since the lack of comparable data inhibits solid interpretations of livelihood change (Ellis 1998, 5; see also Christiansson et al. 1993, 14). The present study considers a period of 40 years, examining changes in popula-

\footnotetext{
${ }^{3}$ Intensification is a concept often used in two different ways. At a farming systems or community level, it is understood as an increase in land use, i.e., as the cultivation of a growing share of the land to which the community has access. This is land use intensification, which is associated with Ruthenberg's R-factor, indicating the proportion of land used in a given season of the total land available (Ruthenberg 1980). However, it may also be understood at the household or field level, where intensification denotes a higher resource input of labor or capital per unit area. In the following sections, we refer to both these forms of intensification but attempt to make clear which meaning is given to the concept in the context.
}

tion, production strategies, land use, and environment in order to ground the livelihood strategies of contemporary Ikuwala in broader processes of changes in markets, resource scarcities, and social relations.

\section{Land Use and Environmental Change in Mazombe Division}

The following section concerns the processes of change in land use and environment that have taken place in Mazombe Division during the last four decades, with emphasis on the case study area in Ikuwala. The changes will be analyzed in a context of population change and settlement and include aspects of intensification/expansion and land degradation. Degradation is understood as processes of environmental change that lower the potential of production and other natural resource use within the present systems of farming and natural resource management, and which do not seem reversible within the framework of the present institutional and socioeconomic setting. Land degradation therefore relates to the opportunities of the current farming population and is not necessarily a question of ultimate irreversibility or crossgenerational time frames. The interpretation of change builds on a variety of sources, as combinations of land use and land cover have been related to the perception of change that the farmers have presented to us in interviews. This allows additional information on the importance attributed to the various processes of change.

\section{The Local Setting}

Iringa District is one of the five districts of Iringa Region and covers a little more than one-third of the area of the region. In terms of population, it is the largest district, even when excluding Iringa town, while in terms of population density, Ludewa, Njombe, and Mufindi districts farther to the south are more densely settled than Iringa Rural, according to the 1988 popula- 


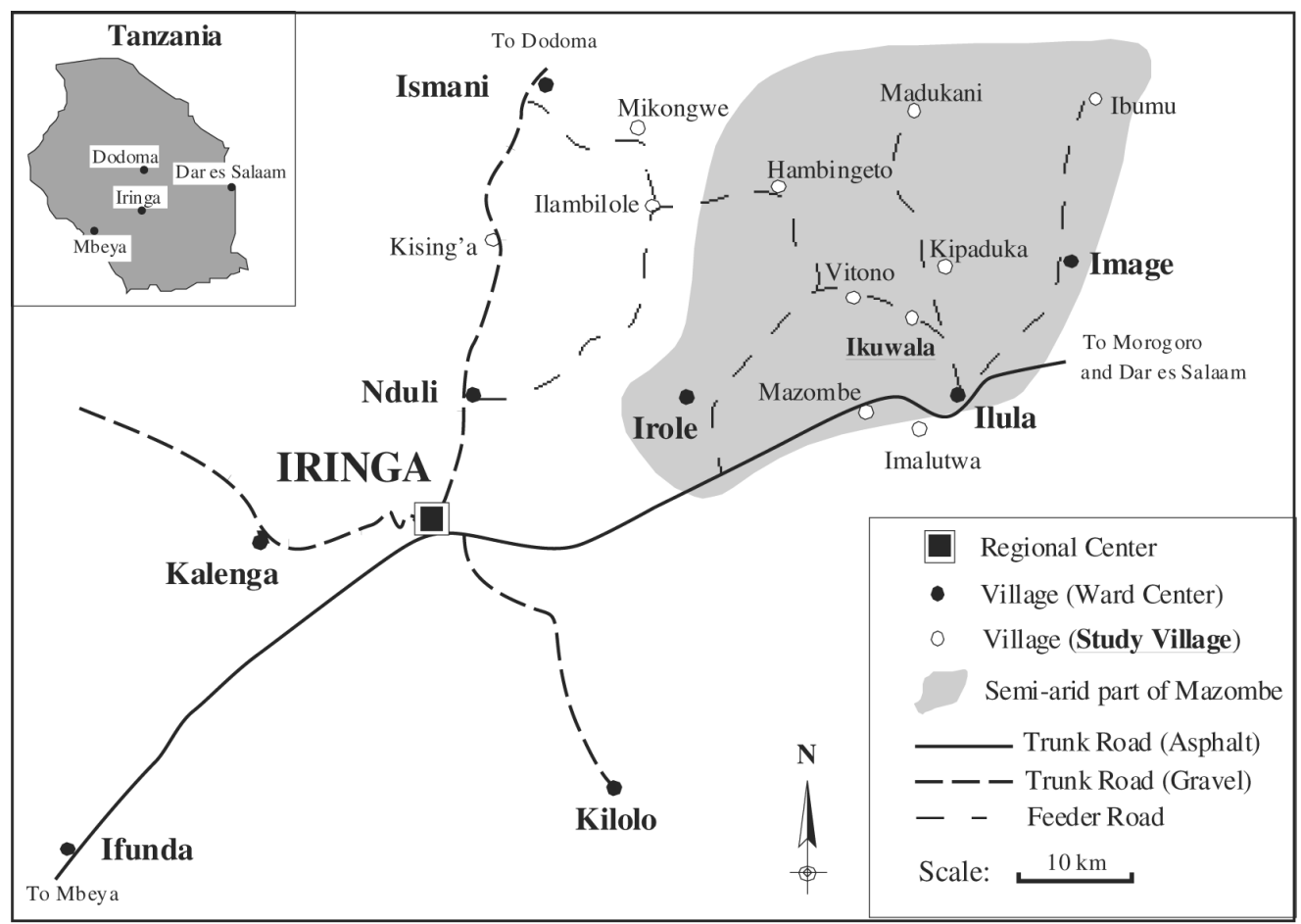

Figure 1. Location of study area, the semiarid parts of Mazombe Division. Source: T. BirchThomsen.

tion census (Lulandala 1994, 67-68). The district has been divided into four agroecological zones: the northern fringe, with a warm tropical climate and low annual rainfall of 550 millimeters; the IsmaniNduli Flats, including Ismani Division, characterized by unreliable rainfall varying between 600 and 700 millimeters; the semiarid parts of Mazombe Division, including the village of Ikuwala (see Fig. 1); ${ }^{4}$ and finally the Kilolo Mountainous Area, with rainfall above 1,200 millimeters. Ismani and part of Mazombe Division thus constitute the semiarid parts of Iringa District.

\footnotetext{
${ }^{4}$ In geomorphological terms, the drier parts of Mazombe Division are part of the IsmaniNduli Flats and Iringa Plain, but with a marginally more reliable precipitation than, for instance, the Ismani Division, located to the west of Mazombe Division.
}

The Iringa-Dodoma road was completed in the 1930s, linking Iringa to central areas of Tanzania, whereas the allweather Iringa-Dar es Salaam road was completed in 1954 (Feldman 1983, 72). Infrastructure development and a growing demand for maize were therefore important in stimulating immigration to and commercializing maize production in Ismani Division in Iringa District. During 1973, when the tarmac road connected the Southern Highlands to Dar es Salaam, some of the national focus on maize production shifted from Ismani in Iringa District to higher-altitude areas with more reliable rainfall like Njombe in Iringa Region and to other parts of the Southern Highlands (see Rasmussen 1986; Raikes 1986; TRDB 1976).

With the increasing traffic on the tarmac road to Dar es Salaam, Mazombe Division was located much more favorably than 
before. Cultivation of tomatoes apparently increased during the 1970s in villages close to the road, such as Imalutwa and Ilula (Kiwasila and Odgaard 1992, 57-59). However, public efforts to promote maize production bypassed the semiarid areas. Whatever commercialization took place in Mazombe was then mainly based on efforts sustained "from below."

\section{Methods of Analysis}

Methods used to analyze land use and cover, settlement patterns, and environmental change rely on fieldwork conducted during the period 1994-98, in combination with interpretation of remotely sensed information in the form of aerial photographs from 1955-56 and 1977-78 as well as satellite images from 1966, 1986, 1993, and 1996. ${ }^{5}$ The fieldwork consisted of group and individual interviews covering such issues as farming systems, village history, and environmental change. Moreover, extensive walks were carried out in the main study village, Ikuwala, with in situ discussions in fields concerning farming methods and land management. Transects yielded ground truth for the satellite image interpretation.

The interpretations of settlement patterns and changes in natural vegetation are based on interpretations of land use patterns, including areas under cultivation and grazing areas, as well as major off-field vegetation types. This analysis covers the Mazombe Plains (for a detailed analysis, see Birch-Thomsen (1996)). Land cover has been analyzed in terms of major vegetation types and covers, while soil erosion has been interpreted through analysis of

\footnotetext{
5 Aerial photos were obtained from the Department of Surveys and Mapping, Dar es Salaam. Satellite images were Declassified Corona Satellite Photography (B/W) from November 1966, SPOT data from August 1986, TM data (bands 2,3,4) from December 1993, and TM data (bands 2,3,4) from August 1996. Refer to Images in the Reference list for full sources.
}

major features (gullies, development of sedimentation fans), as well as through indicators like soil colors and vegetation cover and type. ${ }^{6}$ The image interpretations are supported by field observation from 1994 and 1998 and cover Ikuwala subvillage only. Village interviews - group and individual-supplement the interpretation of the time-series.

\section{Demographic Change}

The growing commercial importance and availability of arable land in Mazombe Division are reflected in the population figures shown in Table 1. According to the census figures, the growth rate of the population in Ismani almost stagnated in the mid-1960s to mid-1970s, while Mazombe Division far surpassed the district average. Even during the decade 1978-88, marked differences in rates of growth are evident between the two neighboring divisions, with Mazombe exhibiting a growth rate of nearly 1 percent above that of Ismani. A process of virtual emigration took place in Ismani after the 1960s due to the shifting priorities of state-supported maize production, whereas Mazombe was characterized by immigration in 1967-78 and population growth similar to the district average in 1978-88. During 1988 population density in Ismani Division was 19 persons per square kilometer, whereas in Mazombe Division it was 36 persons per square kilometer.

The subvillage of Ikuwala, located 5 kilometers to the northwest of Ilula Mwaya on the Iringa-Dar es Salaam road, was surveyed extensively for this study (see Figs. 1 and 2). According to our survey data (Sano 1999), in 1994 Ikuwala was a subvillage of 206 households, with an average size of 5.5 members. This gives an estimated population density of 60 people per square kilometer. Maize is the main staple crop, while

6 For detailed analysis, see Frederiksen (1998). The analysis builds on image enhancements and visual interpretation. 
Table 1

Iringa District Population Data, 1967-1988

\begin{tabular}{ccccccc}
\hline \hline & $\begin{array}{c}\text { Mazombe } \\
\text { Division }(N)\end{array}$ & $\begin{array}{c}\text { Rate of } \\
\text { Growth }(\%)\end{array}$ & $\begin{array}{c}\text { Ismani } \\
\text { Division }(N)\end{array}$ & $\begin{array}{c}\text { Rate of } \\
\text { Growth }(\%)\end{array}$ & $\begin{array}{c}\text { Iringa District } \\
\text { Total }(N)\end{array}$ & $\begin{array}{c}\text { Rate of } \\
\text { Growth }(\%)\end{array}$ \\
\hline 1967 & 32,121 & - & 34,044 & - & 230,881 & - \\
1978 & 47,397 & 3.6 & 35,848 & 0.5 & 290,101 & 2.1 \\
1988 & 58,329 & 2.1 & 40,912 & 1.3 & 363,605 & 2.3 \\
\hline
\end{tabular}

Sources: United Republic of Tanzania 1969, 48; 1978, 100; 1988, 105.

Note: It is unclear whether Ilula Ward has been included in the figures provided by the 1988 census publication. If it has not, the rate of growth for Mazombe Division 1978-88 probably represents an underestimation.

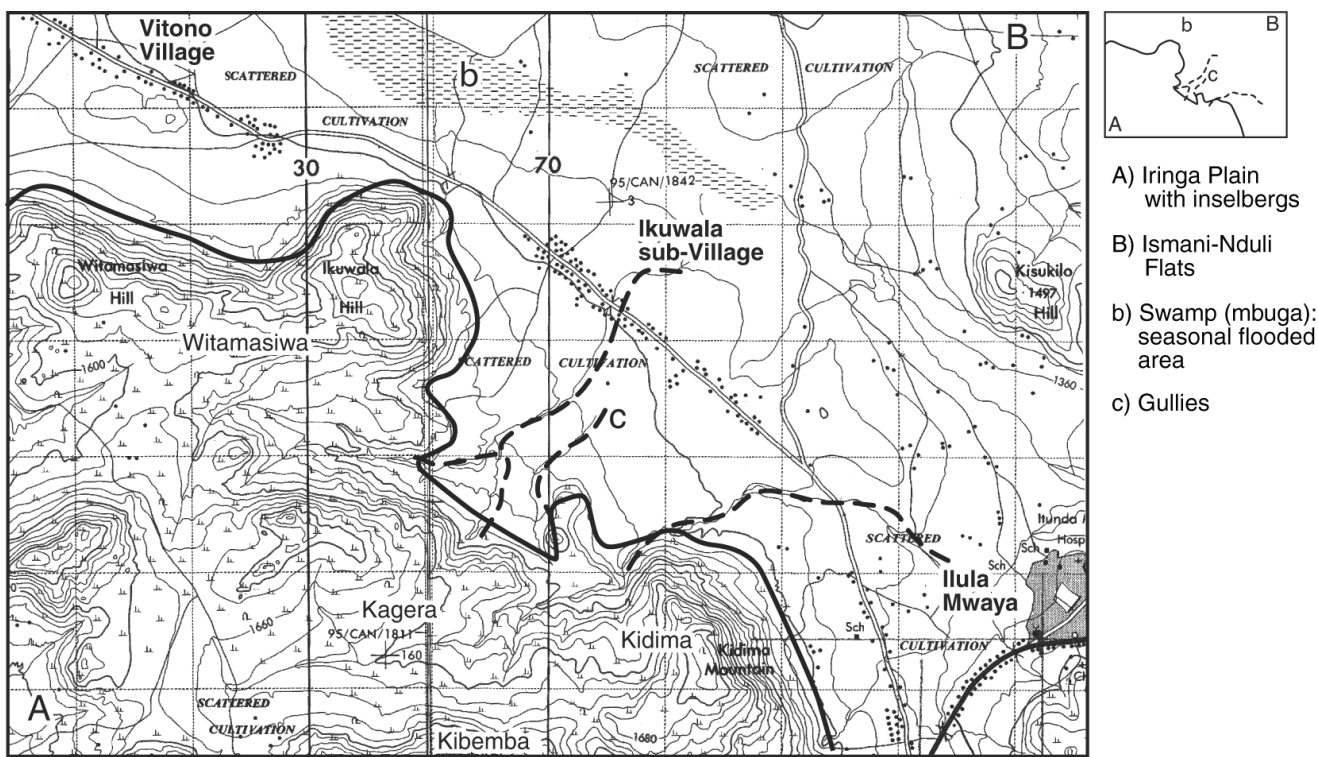

Figure 2. Map of Ikuwala subvillage, located in Mazombe Division, Iringa Region, northwest of Ilula Mwaya and the tarmac road between Iringa and Morogoro. Source: 1:50,000 map of Tanzania. United Republic of Tanzania (1982).

tomatoes, sunflower, and maize are the major cash crops.

\section{Changes in Settlement, Land Use, and Environment}

Since the mid-1950s, the socioeconomic conditions of the semiarid parts of Mazombe Division have gone through major changes as a consequence of - or in addition to-the population increase described above. Aerial photos from 1955-56 reveal that settlement in the Mazombe semiarid area was sparse and located at the base of the hills and on the upper foot slopes of the inselbergs in the area. A more dense settlement structure was located close to the main road to Dar es Salaam. In general, cultivation took place around the settlements and along rivers. The aerial photographs show that natural forest dominated the Mazombe semiarid area in $1955 .{ }^{7}$ A patchy forest

${ }^{7}$ A previous study (EEC 1986) has shown that the few undisturbed pockets of woodland consist of miombo and scrub vegetation of miombo and acacia. This vegetation type is likely to have dominated the natural vegetation at that time. 
clearing and settlement in the northern part of Mazombe indicate that the settlement frontier was on the move, with new homesteads located primarily around the small inselbergs. The area of present-day Ikuwala was still sparsely populated in the middle of the 1950s. Apart from signs of grazing in the area closest to the Ilula Mwaya settlement, the only signs of cultivation were small plots surrounding these settlements (Fig. 3, 1955-56).

Generally, cattle were reported by villagers to dominate the livelihood pattern. Each family was estimated to have in the range of 50 to 100 head of cattle living on fodder grasses from the hills and watering in the swamp (mbuga). The effect of grazing on the natural vegetation in Ikuwala subvillage is clearly revealed on the images. The eastern part of the Ikuwala foot slopes was especially disturbed, since the cattle from Ilula trekked in this direction for grazing and water. The hill plateau and remote hillsides were dominated by natural vegetation, with patches of miombo woodland ${ }^{8}$ on the steeper parts. Several deeply incised gullies crossed the foot slopes (see Fig. 2). These large structures, however, were formed during an earlier period, and by the 1950 s they were relatively stable, with vegetation covering the sides and the streambed and with no signs of large sedimentation fans. In addition to livestock rearing, finger millet was cultivated on bushfields, while maize and beans were intercropped on ridges - mainly for subsistence. The inhabitants explained this settlement and land use pattern mainly by the natural resource availability at that time: water availability along the foot slopes and grazing on the hillsides.

The 1960s and 1970s saw heavy immigration into Mazombe Plains by people from adjacent areas, mainly because of land availability for cultivation and grazing (Birch-Thomsen 1996). The immigration

\footnotetext{
8 The miombo is dominated by the genera Brachystegia, Julbernardia, and/or Isoberlinia (Campbell 1996).
}

to Ikuwala took place during the 1960s and was concentrated on the upper foot slopes along the base of the hills. Settlement and cultivation dispersed over the upper foot slopes throughout the 1960s, and expansion toward the swamp to the north started in the late 1960s (Fig. 3, 1966). A similar expansion of cultivation took place in the area close to Ilula. ${ }^{9}$

In Ikuwala, the expansion of cultivation was favored by the introduction of oxploughing, a new technology which raised the production potential of the heavier soils close to the swamp. This change in technology also affected the cropping pattern toward an increased production of maize and the cultivation method toward flat cultivation. According to interviews (Birch-Thomsen 1996) and image analysis, a similar but slower process of expansion of cultivation took place in the hills. This conversion of the production system toward cultivation was accelerated by cattle diseases, which eradicated a large number of cattle in 1961-62, as well as at the end of the $1960 \mathrm{~s}$, and changed natural resource management strategies immensely. The reduced grazing pressure initially led to regrowth in certain parts of the area. Natural vegetation on less-sloping land was increasingly cleared for cultivation, however, and hillsides became deforested as a result of new grazing patterns and fuelwood collection for household consumption.

\footnotetext{
${ }^{9}$ During the late 1960s, a socioeconomic survey providing information on demographic and productive patterns in Iringa District was carried out in the Southern Highlands (BrannerJespersen 1971). It included two enumeration areas in Mazombe Division close to the main road linking Iringa to Dar es Salaam. According to this study, some of the basic elements that prevail in present-day livelihood strategies were already apparent in the productive patterns during the late 1960s: a reliance on crop production, with maize being the dominant crop, though often intercropped, and production of tomatoes, the cash importance of which was not documented, however.
} 


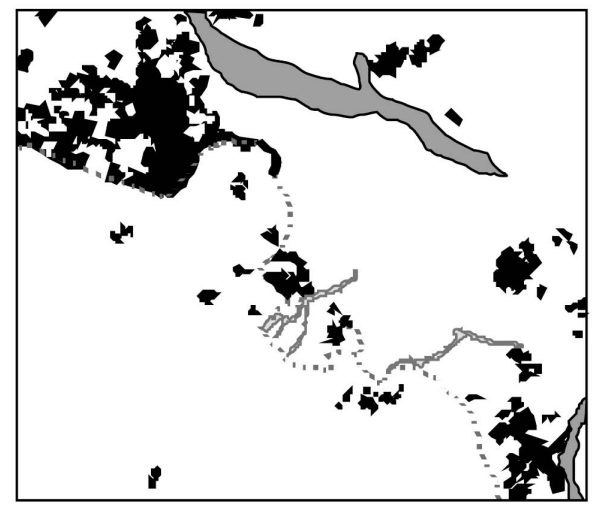

1956

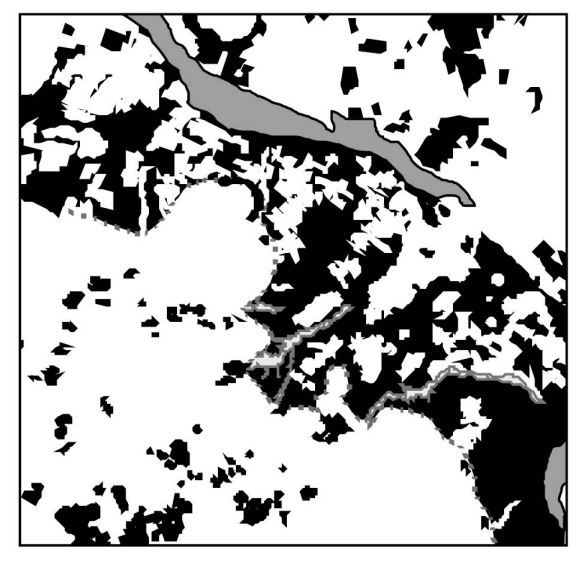

1978

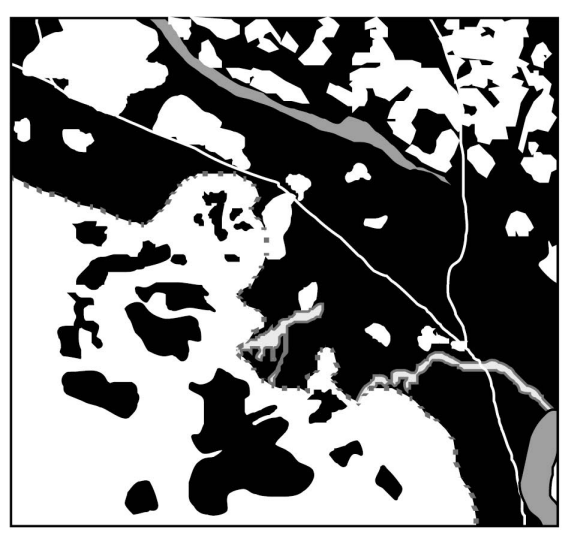

1996

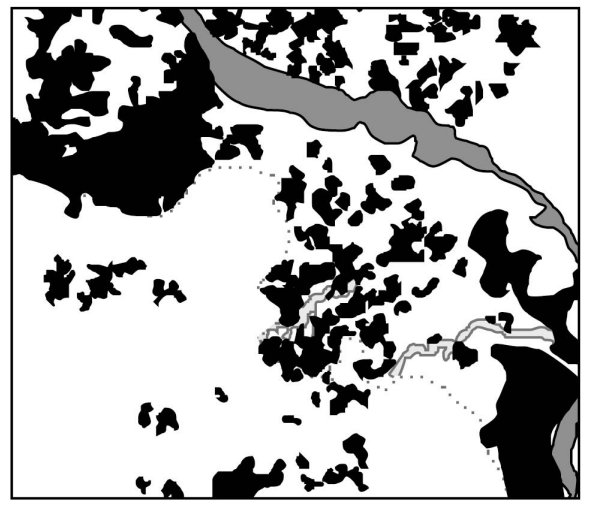

1966

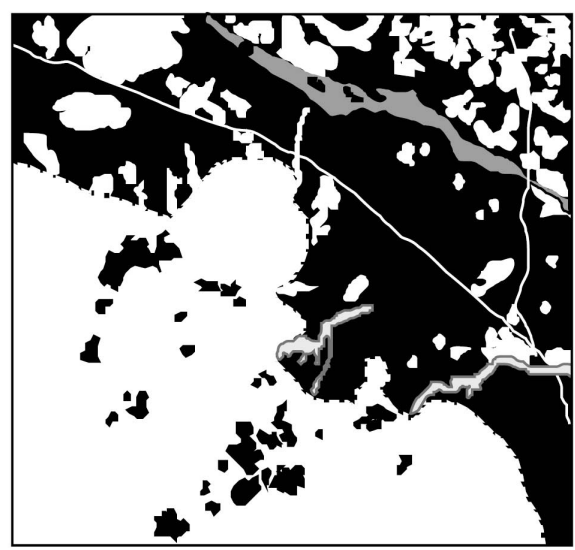

1986

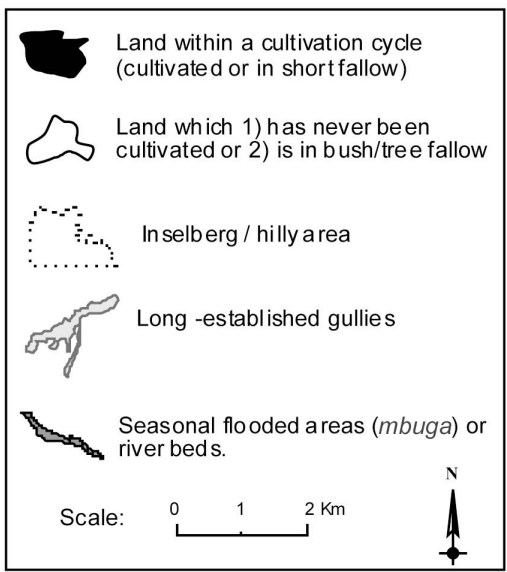

Figure 3. Land use changes in Ikuwala subvillage, 1956-1996. Source: 1956 aerial photography; 1966 declassified satellite photography; 1978 aerial photography; 1986 SPOT-image; 1996 TMimage. Refer to Image reference list. 
During the 1960s, animal traction was restricted to a minority of the population, whereas the process of adoption took place rapidly during the 1970 s and 1980s. At the end of the 1970s, upland tomato cultivation on rainfed fields was adopted as part of the production system. A number of households also acquired access to irrigated garden land where tomatoes could be grown throughout the year. This crop spread rapidly in the village, becoming an alternative to maize as a cash crop.

Aerial photos from 1978 show that the Mazombe Plains were now inhabited and cultivated extensively, with few pockets of natural forest left, except for the Image Forest Reserve. A major change in settlement pattern and localization took place as a result of the villagization process, 1974-76, where people were moved together in nucleus villages, often with an element of coercion. As formerly documented from other parts of Tanzania (see, e.g., Birch-Thomsen 1993; Kikula 1997), this gave rise to intensified land use around the newly settled villages and to more extensive practices in the more distant fields. The immediate effect of villagization in Ikuwala was that some of the peripheral areas in the hills experienced a period of vegetation regeneration. This was shortlived, however, since farmers started to recultivate old and more remote fields a few years after the resettlement (BirchThomsen and Frederiksen 1995). By 1978, the area seems to have reached a minimum of vegetation cover: the foot slopes were cleared for cultivation, and to a large extent the hillsides had been turned into bushed grassland (Fig. 3, 1978). Cultivation expanded upward from the bottom of the hills on slopes of 5-10 percent, and sheet erosion was probably accelerating, although it is not easily detectable on the images. Bright soil colors indicate disappearance of topsoil. Similarly, cultivation spread to the very edges of the large gullies intersecting the area, as well as to the edge of the swamp. The large gullies had been reactivated, vegetation in the bottom had disappeared, and sedimentation was now visible at the gully outlets. New gullies were under development, especially in the old cattle tracks and on the newly opened land on the valley sides. Downslope, new rills were working their way toward the older, large gully structures.

Satellite images from 1986 and 1996 (Fig. 3) indicate pressure on land in the Ikuwala area, where the edge of the swamp retreated significantly, giving way to cultivated fields. Expansion of cultivation took place in the hills during the late 1980s and 1990s, as more people settled in these parts of the village area (Kagera Plateau). Observations made during the project period show that vegetation cover is still on the decrease in the hill areas. Charcoal production takes place on a commercial, if not legal, basis, leaving hillsides deforested but covered by grass and herbs. Some areas of the hilltops are cultivated after tree felling, leaving the soil bare for parts of the year. Steep hillsides and valleys are being cleared for cultivation and cultivation is now taking place upslope from the old settlements at the base of the hills.

Informants stated that fallowing was increasingly rare on the foot slope fields and that individual fields had often been continuously cultivated since the late 1970s. In 1998, cultivation of marginal areas on the hillsides (> $35 \%$ slope) and in the valleys along the small streams draining the hills was clearly on the increase. Villagers had a clear perception of a decrease in soil fertility within the last three decades, substantiating this by the amount of land required to feed a family then and now. According to the socioeconomic survey carried out in the whole village in 1995, the average household yield of maize was approximately 450 kilograms/hectare (2 bags/acre). ${ }^{10}$ Generally, fallow practices have decreased significantly and fields are only left fallow when the yields decrease "below what is acceptable." This, in combination with current practices of trading and renting land as the

\footnotetext{
${ }^{10}$ One bag is the equivalent of 90 kilograms.
} 
now dominant way of acquiring new land, and added to the picture of land pressure, supports the villagers' perception of decreasing soil fertility.

In 1998, a year of extremely high rainfall, a majority of farmers interviewed stated that erosion had become worse during the preceding years. They experienced soil erosion as a serious problem, causing either a decrease in productivity following removal of nutrients or seeds and seedlings to be washed away and crops buried under sandy sediments downslope. One elderly female farmer, reporting that houses were being flooded during recent years, described accelerated erosion of footpaths by livestock, tractors, deforestation, and population increase after villagization. Generally, however, there was no consensus among the villagers as to the causes of soil erosion, but deforestation in the hills was often mentioned. According to the villagers, trees were more abundant before villagization and deforestation in the hills was related mainly to charcoal production.

Fieldwork conducted during 1994 and 1995 confirmed this pressure. The areas north of the road were almost completely under cultivation, with new fields being opened close to the swamp. The increasing number of fields in the swamp (especially visible on the 1996 image, Fig. 3) were made possible by digging ditches to drain the area. The farmers explained that expansion was facilitated by a decrease in rainfall. However, identification of a general decrease in mean yearly rainfall in the study area has not been possible (pers. comm., J. R. Jensen, SASA researcher from The Royal Veterinary and Agricultural University, Copenhagen, November 1998). An alternative explanation to the perception of a decrease in rainfall by farmers could be a relative increase in the agricultural dryness as a result of changes in the hydrological regime. Changes in the vegetation cover in the watershed may have reduced the infiltration rate and the water retention capacity, leading to an increased runoff with a possible siltation of the swamp as a result. Evidence of siltation linked to gully outlets near the swamp is visible on recent images.

Evidence of accelerated runoff and erosion are abundant in the area. On the foot slopes, some larger patches of land in the eastern part are left fallow, probably because of low productivity. Major areas on the upper foot slopes are affected by serious soil erosion, and rills are abundant throughout the area, in some places developing into gullies. Rills are also found on the middle part, though less frequent, while sedimentation takes place simultaneously in a general process of transportation. Along the lower course of the gullies, stream bank erosion removes agricultural land. On a minor scale, farmers reclaim land within the gully floor for cultivation. On the lower foot slopes, the problem of sedimentation is increasingly felt as rills and gullies end up flowing into a field and washing away or burying the crop. Shrubs and trees have disappeared from the swamp, and cultivation encroaches on the remaining grassland. Although this may not be termed degradation, because it actualizes a new potential for cultivation, it has repercussions for the grazing potential within the village.

Hardly any soil conservation effort is observable. When directly affected one year, some farmers tried to redirect the flow of water by digging a trench off the field. Other farmers have ploughed a ridge upslope, above the field, but this is only a small effort compared to the extent of the problem.

The changes within the last five decades in Ikuwala are summarized in Table 2. During the late 1950s and early 1960s, agricultural practices began a process of change. A combination of permanent cultivation on ridges close to settlements and shifting cultivation on more remote fields changed toward more widespread use of permanent cultivation on flat fields ploughed by ox-ploughs or in a few cases tractors-a process paralleled by a decrease in the number of livestock. This change was a reality by the mid-1980s, when most of the land on the foot slopes 
was brought under cultivation. No change or very little change in agricultural practices in this part of the village area has taken place since then. However, the expansion of agriculture, observed within the last decade, into new areas such as the swamp and the hills supplement this picture. New techniques for draining the wetlands have been introduced, while old forest slash-and-burn techniques in combination with charcoal burning were revived. In terms of land use intensification at the village/community level, a clear picture of agricultural expansion is evident, whereas intensification of farming practice is more questionable. The introduction of animal traction made an expansion of the area under cultivation possible without necessarily intensifying labor use due to the substitution of manual labor by animals (oxen). On the other hand, through the introduction of cash crops with additional external inputs, farming became more capital-intensive.

The most recent development, with agriculture expanding into the wetlands, has introduced more labor-demanding methods and resulted in labor intensification. At the same time, some farmers have reintroduced the labor-extensive cultivation techniques of slash and burn in the hills, though often accompanied by labor invested in charcoal burning. Thus, the case of Ikuwala represents a process of environmental change that in some respects can be deemed land degradation. The foot slopes are exhausted to such a degree that longer fallow periods or additional inputs are needed in combination with soil conservation upslope in order to regenerate soil structure and fertility. Gully development is taking its toll on agricultural land. While the villagers blame charcoal production for the state of natural resources, it may not be the major cause of increased soil erosion. ${ }^{11}$

\footnotetext{
${ }^{11}$ While charcoal production may not be the major cause of soil erosion, botanical studies have shown that the miombo species (Brachystegia speciformis), preferred for charcoal and fuelwood, has been nearly depleted
}

The grass layer under the trees and scrub is to a large extent undisturbed after the felling of the trees unless cultivation follows. When deforestation is combined with cultivation, however, it leads to sheet and gully erosion on steeper slopes to the extent that the bedrock is exposed. These processes can be termed irreversible within a time span of relevance to the users.

\section{Current Livelihood Strategies at the Community Level}

The foregoing analysis has shown how maintenance and intensification of resource use have historically been limited in the study area. In the following section, we seek to explain why this is the case through an analysis of the current livelihood strategies in the Ikuwala community. The livelihood analysis concerns questions of how individuals and households mobilize, combine, and decide over resources, but also of how individuals or groups relate to each other, given their diverse resource use and management strategies. The livelihood analysis thus leads to a social analysis of strategies and patterns of adaptations to changing conditions and hence of various groups' room to maneuver (see also Reitsma, Dietz, and de Haan 1992, 38-40; Bebbington 1999, 2022-23). The approach thus relates to the capacity to act and change from below.

In this paper, the analysis of livelihood strategies in Ikuwala mainly concerns an analysis of resource use and combinations related to income sources, land use, and land management. The discussion of adaptive strategies and room for maneuver is only preliminary. Less emphasis is put on access to resources and mobilization through, for example, networks and social identities. Institutional factors are thus downplayed, while livelihood strategies are analyzed primarily as income and allocation strategies of respective groups. The quantitative data used are based on data collection over two years. Detailed house-

and that it may disappear altogether if protective measures are not taken (Ndangalasi 1998). 
Table 2

History and Indicators of Environmental Change in Ikuwala

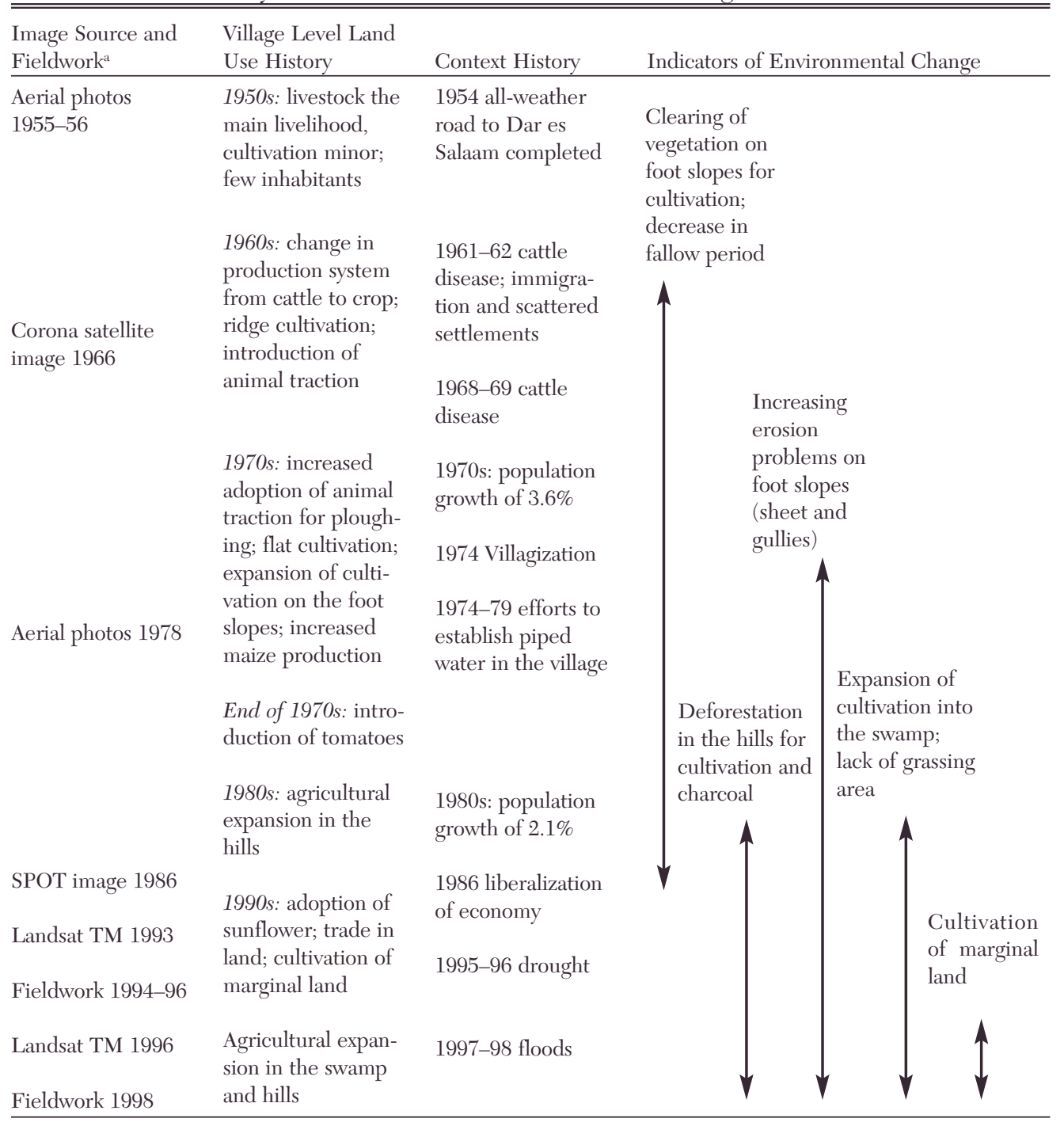

a Refer to Images in References.

hold interviews contributed important qualitative information on the diverse livelihood strategies of the area. Concerning the interrelationship between groups and their different strategies, it should be kept in mind that since the study area is semiarid, it is strongly influenced by annual variations, and such variations, may influence both the proportion of house- holds in different categories and their economic activities.

\section{Socioeconomic Differentiation}

A two-step process of fieldwork forms the entry point for the following analysis. A socioeconomic survey was undertaken with a random sample of 35 households in the village of Ikuwala (of which 34 are included 
in the data base). ${ }^{12}$ This survey included questions on sources of income, but also on agricultural production and marketing. As a next step, detailed and open-ended interviews on earnings from diverse income sources and on issues of decision making were undertaken with individual household members in 10 households. These households were selected according to their socioeconomic position and their pattern of income sources. Similar fieldwork was undertaken in two other villages located in Mazombe, but information from these analyses is used only to support conclusions drawn in the following.

Wealth ranking was used in identifying criteria of wealth and poverty. The method has been described in Sano (1999). For other wealth-ranking exercises in Tanzania, see Boesen and Ravnborg (1992) and Mung'ong'o (1995). On the basis of the wealth ranking and the interpretation emerging from the interviews, six indicators of inequality were used in differentiating the households. These indicators are (1) acreage cultivated (farming ability); (2) tomato sales-that is, earnings from the most important cash crop in the respective villages (access to money); (3) whether members of the household worked as wage laborers (the need to depend on others for work); (4) payment for wage labor (the ability to hire additional farm workers); (5) the number of cattle owned (access to cattle and capital); and (6) whether the household was forced to buy or borrow food during the previous season (food security).

The villagers participating in the wealth ranking divided their neighbors into two, three, or four groups: a group of impoverished households disadvantaged on nearly

${ }^{12}$ The SASA study comprised five villages in Iringa District and one village in Rujewa District. Some of the dimensions of livelihood strategies discussed in the context of Ikuwala also prevailed in, for instance, Ilambilole and Mkulula villages. For an early comparison of livelihoods and poverty in Mkulula and Ikuwala respectively, see Sano (1999). every score; an intermediary group that included some with a certain potential for development and others likely to fail in their endeavors; and an upper-middle or advanced group that included a few outstanding households. Based on the detailed household interviews, in combination with the wider household survey, we formulated three hypotheses.

First, it became apparent that three major strategies characterized households in the area: a strategy of accumulation, with enterprising and commercially oriented farmers in the center; a peasant strategy, which expressed both restraint toward the market economy and failure to be successfully involved in it; and finally, a strategy of sometimes nearly desperate coping with whatever means the household had at its disposal. Second, strategies of accumulation pertained to a larger group than those farmers who were characterized as well-todo or wealthy in the wealth ranking. Accumulation strategies related not only to household ownership, but also to a wider access to resources most often obtained within the extended family. Moreover, choice of strategy was not only a question of narrow resource access, but also of attitudes toward risk, market relations, and identities within particular groups. Third, households' strategic choices related in some way to age. Accumulation strategies could thus be pursued by relatively young unmarried men or young couples who were still strong, whereas peasant restraint or coping strategies were sometimes also dictated by age and relative weakness of the householders.

Our argument is thus that livelihood divisions say more about resource management than socioeconomic divisions, because inherent in the concept of livelihood strategies is a notion of actual resource use, whereas the socioeconomic division may only relate to this theoretically. Differentiating according to livelihood strategies attaches importance to actual resource use and allocation rather than to formal access. 


\section{Livelihood Strategies at the Household Level}

Definitions. The criteria suggested in the wealth rankings are all associated with the agricultural economy. It also became clear from the wealth ranking that wealthy or well-to-do households centered their strategy of accumulation on agricultural production. However, as indicated above, the socioeconomic division based on household resources blurred to some extent important differences related both to the type of resources from which wealth was derived and to the type of resource allocation undertaken by the householders. Particularly in the intermediary group defined according to wealth criteria, some of the householders who were in the same category in a wealth ranking exhibited different patterns of resource use and allocation. Some had a pattern much more closely related to the well-to-do farmers, whereas others were almost as defensive in their strategies as the poorest householders. Some of these intermediary households were not well-to-do, but they were enterprising.

When considering the households that revealed an enterprising and accumulating strategy in the detailed household interviews, it became clear that they were all characterized by a fairly high agricultural income level and by a pattern of income sources which implied that they obtained incomes from business or crafts. Likewise, the poorest group was associated with a low level of agricultural incomes and with an income pattern where piecework, possibly combined with incomes from natural resources, played an important role. The level of agricultural income in combination with the pattern of income sources of the household were therefore used as indicators distinguishing one livelihood group from another.

The peasant-labor coping strategy is the designation of the poorest livelihood strategy. It was given this designation to associate this livelihood strategy with piecework and with efforts merely to cope. It is asso- ciated with low agricultural income (five out of ten households had agricultural income below Tsh 5,000 in 1994) ${ }^{13}$ and with piecework and income from natural resources (mainly from the collection and sale of thatching grass and fuelwood) as the important cash earners.

The peasant strategy was associated with nonaccumulating strategies and with a propensity not to take too much risk and not to engage strongly in the commercial economy. This group had intermediary agricultural incomes, some quite low (5 out of 11 households had incomes below Tsh $35,000)$. However, this group was also characterized by a vacillating income pattern between, on the one hand, piecework and natural resources, and, on the other, business, rents, or crafts.

The accumulating farmer strategy was associated with a pattern of resource allocation clearly aimed at accumulation. This group had fairly high agricultural incomes and a pattern of income sources based on business, crafts, and rents. However, members of this group were often quite young household heads-in some cases unmarried men-who depended on help from their fathers or the family network. Members of the accumulating group often displayed a diversified income pattern. They sought to invest incomes derived from agriculture in other income-generating schemes such as kiosks, masonry, maize trade, or investments in housing.

The divisions were undertaken in the following manner: agricultural incomes (Tsh) were divided into four groups based on frequency of distribution: levels from 0-15,000 scored 0 points, from 16,000-75,000 scored 1 point, from 76,000-200,000 scored 2 points, and 201,000 and above scored 3 points. Incomes from natural resources: yes scored 0 points, no scored 1 point. Incomes from piecework: yes scored 0 points, no scored 1 point. Incomes from crafts: yes scored 1

\footnotetext{
${ }^{13}$ The rate of exchange in 1994-95 was 1 U.S. dollar $=500 \mathrm{Tsh}$.
} 
point, no scored 0 points. Incomes from business: yes scored 1 point, no scored 0 points. Incomes from rents: yes scored 1 point, no scored 0 points. The livelihood classification is thus based on six variables, with a maximum score of 8 points and a minimum of 0 points. Based on the distribution of particular income sources within the score groups, households scoring 0-2 points were classified as peasant-laborers, households scoring 3-4 points were classified as peasants, and households scoring 5-8 points were classified as accumulating farmers. While the livelihood classification is thus based on analysis of frequency, the selection of indicators was based on observations made during qualitative interviews. Note that several methods of livelihood classification were tried with the same indicators. A core group of 18 households were always placed in the same category, while 16 households, mostly in the middle of the continuum, located themselves with some variation according to the method used.

Characteristics. It is now possible to consider the various livelihood strategies, as presented in Table 3. The peasant-laborers constituted only 29 percent of the sample. Four out of ten households were female-headed, and the average age of the group was 42 , with little variance around this mean. As indicated in the table, they relied strongly on their own labor as a means of raising money or food. In addition, they depended on off-field natural resources, in the form of grass cutting and firewood collection, for sale or for beer brewing. Thus, the state of natural resources and the distance to the resource became important circumstances for their resource allocation. Although some peasant-laborers might depend on charcoal burning, this was more difficult to ascertain, since charcoal burning is illegal. Moreover, they all cultivated land; land thus remained an important resource in their livelihood strategy, not only because it provided basic food, but also because it provided grain for beer brewing. Indeed, beer brewing remained an important income source for all households across the sample. Sunflower and tomatoes were sold at low levels by peasant-laborers, but whatever maize was grown was retained for household consumption.

The group coped with the impossible either because household heads were often too weak to work, because they were single with a number of dependants, or because

Table 3

Livelihood Strategies, Average Age of Household Head, and Income Sources

\begin{tabular}{|c|c|c|c|c|c|c|c|}
\hline & \multirow{2}{*}{$\begin{array}{c}\text { Average } \\
\text { Age of } \\
\text { HH Head }\end{array}$} & \multirow{2}{*}{$\begin{array}{c}\text { Average } \\
\text { Crop Income } \\
\text { in Tsh } \\
\text { (U.S. \$s) }\end{array}$} & \multicolumn{5}{|c|}{ Percentage of Households (HH) Reporting Incomes from } \\
\hline & & & $\begin{array}{c}\text { Natural } \\
\text { Resource }^{\mathrm{b}}\end{array}$ & Piecework & Crafts & Business & Rents \\
\hline $\begin{array}{l}\text { Peasant-labor } \\
\text { coping strategy } \\
(N=10)\end{array}$ & 42 & $\begin{array}{c}15,500 \\
(31)\end{array}$ & 60 & 70 & 20 & 20 & 0 \\
\hline $\begin{array}{l}\text { Peasant } \\
\text { strategy } \\
\quad(N=11)\end{array}$ & 41 & $\begin{array}{c}65,500 \\
(131)\end{array}$ & 18 & 45 & 45 & 27 & 18 \\
\hline $\begin{array}{l}\text { Accumulating } \\
\text { farmer strategy } \\
(N=13)\end{array}$ & 34 & $\begin{array}{c}430,000 \\
(860)\end{array}$ & 0 & 0 & 46 & 54 & 62 \\
\hline
\end{tabular}

Source: Village survey (1995) and qualitative household interviews (1996) carried out by SASA research team.

${ }^{a}$ Rate of exchange in 1994-95 was U.S. $\$ 1=500$ Tsh.

${ }^{\mathrm{b}}$ Includes activities such as grass-cutting, firewood collection, basket and storage facility production. 
they were without access to resources. One example in this group is a single woman aged around 35 with no dependants $(\mathrm{HH}$ No. 11). She cultivated 0.4 hectares of maize intercropped with sunflower and cowpeas. The woman indicated that sale of natural resource products was her major income source, but it became apparent that piecework had been an equally important income source during the previous season. She had earned Tsh 6,000 from doing piecework three times, Tsh 2,000 from selling ten bundles of firewood, and Tsh 6,000 from selling one drum of beer. She had produced two bags of maize, but this could hardly sustain her through the season, as grain was also used for brewing beer. Although she originally reported that she did not receive any help from other people, it became apparent during the interview that she had received finger millet from others for beer brewing.

The peasant strategy characterized 32 percent of the households and can be described by a limited market involvement and the absence of a long- or medium-term strategy of change. Two out of 11 households were female-headed. The average age of the heads of households within this group was 41 , but with a greater number of young or comparatively old households in the group. Five household heads were thus below the age of 35 and three were more than 55 years old. The majority of households within this group may have opted for the peasant strategy because they had no other choice. However, a minority within the group adopted a peasant strategy because they shied away from a more commercialized pattern of income generation that they found too demanding for various reasons.

The level of crop marketing was not impressive in the peasant group, although they could hardly be characterized as subsistence producers. Five of the households had agricultural incomes below Tsh 35,000 . However, in contrast to the peasant-laborers, most households in this group attempted to gain some earnings from tomatoes, while also earning agricultural incomes from sunflower. Of the average agricultural earnings of Tsh 65,000, sale of tomatoes made up 52,000. Even in this group, maize was retained for household consumption. Nonagricultural income derived mainly from crafts and petty commerce, but piecework and natural resources in addition to beer brewing were also important. While nearly half of the group participated in piecework, almost none of the households, either in this group or among the peasant-laborers, employed wage labor themselves. Only two households in each group did so, in very modest amounts.

One example of the peasant group is a family of five (HH No. 20), with one wife in the household. Income from crop sales was cited as the major cash income source, but supplementary incomes derived from beer sales, sale of firewood and charcoal, in addition to piecework. Tomatoes earned the family Tsh 80,000 , while 52,000 derived from the other income sources during 1994-95. The family employed no pieceworkers themselves.

Substantial crop incomes and diversified income sources from business, crafts, or rents characterized the accumulating farmer households. This group constituted 38 percent of the sample. The average age of household heads was 34, reflecting the fact that eight heads of households were below 35, while only one head of household was more than 55 . The majority of the group was thus young enterprising farmers, possibly supported by their fathers, while the remainder represented the small group of wealthy farmers in the village, most of them middle-aged. No heads of households were female.

The major income earner in this group was tomato production, possibly combined with maize marketing. Tomatoes accounted for almost Tsh 350,000 of the average earnings of the accumulating farmers (see Table 2), while maize accounted for nearly Tsh 80,000 of total agricultural earnings. Growing tomatoes represented an avenue into and a source of accumulation, in contrast to the poorer livelihood 
groups' reliance on sunflower production. Apart from agricultural incomes, accumulating households typically diversified their commercial activities. As a result, they earned substantial incomes from renting tractors or oxen to fellow farmers or from trading in maize. In addition, their wives contributed with substantial earnings from beer brewing and possibly from some other trade. The accumulating farmers did not obtain any substantial cash incomes from natural resources, and they did not take part in piecework. On the contrary, the accumulating farmers were the employers in the village. Eight out of 13 households hired wage labor, at an average of Tsh 26,500 for the whole group.

The most striking example in the group was one of the wealthiest farmers in the village (HH No. 21). He cultivated 24 hectares in the village and had access to an additional 171 hectares, some in neighboring Vitono. He had expenses of Tsh 200,000 for wage labor, but earned Tsh 1.2 million from tomatoes. Moreover, Tsh 50,000 were earned from selling vegetables, 700,000 from maize trade, and 180,000 from renting his tractor to other villagers. Both of his wives earned more than Tsh 30,000 from selling beer. One of them also earned some funds from chicken trade.

This scale of operation is outstanding, but other members of the group were engaged in similar accumulating operations on a lower scale. They strove to expand their agricultural production or other activities. One such example was a young household in their early 20s (HH No. 7). The husband worked as a mason and maize trader, but earned additional income from renting a plough to neighbors. They cultivated a comparatively small area-only 1.6 hectares-but stated that they earned most of their income from agriculture. They even hired a laborer to help them clear the land. They earned Tsh 110,000 from selling tomatoes and 19,500 from sunflower. They used all their maize for their own consumption, but the husband's newly started masonry business allowed him to engage in maize trade. For religious reasons, the wife brewed no beer, but she engaged in firewood collection and sale. The very energetic husband described how he had first earned money from selling water, then from breeding goats. He invested these earnings in pesticides for tomatoes. Their present plan was to expand maize production while continuing to grow tomatoes and sunflower, along with the masonry.

The accumulating farmer strategy was highly dependent on access to land, while other natural resources were not as important. Access to and control of capital was also important in this group. Control over capital and connections provided this group with good opportunities to rent or monopolize good land in both Ikuwala and the neighboring villages.

\section{Livelihood Strategies, Land Management, and Access to Resources}

A number of features reported by the farmers in Ikuwala indicated an unsustainable agricultural economy characterized by low crop output per hectare, declining soil fertility, and erosion. In this section, we discuss the relationship between different livelihood strategies and land management practices. The point of departure is mainly the maize economy, as maize remains the most important food crop and an important source of income in the area.

As stated earlier, land productivity in Ikuwala was very low-especially on the central village lands-and all farmers reported low yields of maize. Average yield levels of the three livelihood groups were 310 kilograms/hectare (1.4 bags/acre) for peasant-laborers, 400 kilograms/hectare for peasants, and 645 kilograms/hectare for accumulating farmers; land productivity thus corresponded to the livelihood strategies. A few outstanding farmers reached substantially higher levels (approximately 1,000 kilograms/hectare was the maximum yield in the sample), but a large majority of the farmers reported fertility declines and that soil erosion was an ongoing phenome- 
non on their land. Whatever measures of intensification and soil conservation farmers undertook, they seemed to be insufficient to restore reasonable land productivity $^{14}$ or even to halt the exhaustion and erosion of the land. Although some farmers clearly did not have the ability to invest many resources in their land, others did have some capacity for investment. Therefore it was of interest to investigate why these investments were so poorly reflected in land productivity.

In order to explore land management within the three groups of farmers, we employed data from the quantitative survey as indicators of intensification and land management. Two issues in particular were examined: access to resources for intensification and fertility management and flexibility in resource allocation. Intensification is indicated by the inputs used: propensity to use manure, to use chemical fertilizers, and to apply improved seeds. Data on labor inputs in relation to farmed area were not collected, but we considered investment in working parties as well as hired labor as indicators of relative intensity of land use. Indicators of fertility improvement in farm practices are residue incorporation, composting, and monocropped beans.

In addition, we explored the access to resources necessary for flexible management. Positive harvest results in semiarid areas are to a significant degree dependent on the ability of the farmers to have flexible access to resources in order to put them to use at the right time (Adams and Mortimore 1997). Thus, some resources become important at certain-variabletimes, like access to tractors, oxen and ploughs when the rain starts, seeds when it is time to sow, and labor for weeding.

\footnotetext{
${ }^{14}$ In the village areas surrounding Ikuwala, the land productivity was much the same as in the central village areas that had been under cultivation for many years. The best results showed yields of around 2.2 tons per hectare (10 bags/acre).
}

The accumulating farmers were significantly better off on all indicators than peasant-laborers, who moreover lost flexibility by hiring out their own labor at critical times. The peasant group accessed labor through traditional beer parties to a higher degree than the other groups. However, the differences in input use discussed below hardly seem to account for the differences in land productivity to any major extent.

Manuring the maize fields was only practiced by a few of the peasant-laborers, whereas approximately 50 percent of the other groups used manure on the crops. Generally, small quantities of manure were applied, mostly in the planting holes. Improved maize seeds were not used to any large extent, and almost exclusively by about one-third of the accumulating farmers. This practice was not reflected in the reported yields. The major users of artificial fertilizer were the accumulating farmers (60 percent of the group using fertilizer, but almost exclusively on tomatoes). Other fertility-improving practices were carried out by less than 25 percent of the farmers, but there was no clear pattern as to which farmers used these measures. All farmers stated that they now practiced only flat cultivation.

Peasant-laborers were to some extent restrained in their access to labor, while the two other groups used different arrangements in order to gain access. These arrangements included traditional working parties rewarded with serving of beer, which was still frequently arranged especially by the peasants, but also hired labor, which was used by two-thirds of the accumulating farmers, but also by other farmers on a smaller scale.

Only two farmers, belonging to the accumulating group, owned a tractor, while ploughs were owned by two-thirds of the accumulating farmers and by around onethird of the other farmers. Ploughs, oxen, or tractors were hired at one time or another by a quarter of the farmers, but there was no large differentiation among the groups. Since most fields were 
ploughed, it is likely that the peasant-laborers and peasants participated in ploughing systems - that is, arrangements with the owner of the plough, wherein payment takes different forms (see also BirchThomsen 1993; McIntire, Bourzat, and Pingali 1992). As we saw above, there was a strong relationship between livelihood strategy and the employment of wage labor, on the one hand, and participation in piecework on the other. Thus, there is a strong indication that the accumulating farmers were much more flexible in their ability to apply farming resources at the appropriate time than the peasant-laborers. The latter may have to work for others at the optimal planting time or wait for a vacant plough, making them more vulnerable in terms of dependence on soil conditions, rainfall, and timing in general.

Differences in manure application and access to labor, oxen, and ploughs may go some way in explaining productivity differences, but not all. Access to fresh land provides an additional, and very important, explanation. Table 4 shows access to land among the three groups, according to type of access. Systematic differences emerge, as the accumulating farmers access larger areas and through various ways of appropriation. Cultivated land in the group of accumulating farmers was double that of the other groups, and approximately 20-25 percent of the total area was not cultivated for various reasons. Buying land remained a more common strategy among the accumulating households, even though the peasant-laborers additionally bought small pieces of land. Even borrowing or renting land seemed easier for the accumulating farmers. This was also valid for the practice of acquiring land in other villages. While farmers in all groups had access to some land in other villages, significantly more members of the accumulating households ventured into that kind of arrangement. These opportunities may contain the most significant factors in explaning productivity levels. Land acquired in neighboring villages is predominantly located close to the swamp. It is evident that the land near the swamp both in Ikuwala and neighboring Vitono is more fertile than the exhausted foot slope land because of its location on the bottomland, where the nutrients accumulate. The water retention capacity is better, and the cultivation history shorter (see Fig. 3). ${ }^{15}$ These areas are likewise most suitable for tomato cultivation, but risky in flood years.

Thus, the accumulating farmers, who operated with favorable conditions in terms of access to ploughs, oxen, and labor, had been able to acquire land near the swamp, and they were capable of taking the risk of cultivating the low-lying land. As already mentioned, some farmers had even invested in drainage canals. The majority of the tomato fields are also found in this area north of the road. The reasons for seeking out land in neighboring villages are much the same. Thus, strategies for maximizing output and income are more related to expansion on fertile land suitable for production of high-value marketable crops than to intensification on central village land.

It is this expansionist strategy that has resulted in the heavy encroachment on the swamp, as evidenced by the remote-sensing data. What seems important in the accumulating strategies is thus the ability to mobilize such resources as fertile land for expansion of cultivation; strategic means of production, including labor; and

15 Preliminary results from ongoing studies within SASA (Birch-Thomsen) indicate a variation in maize yields related to the location and history of fields. On the upper foot slopes, and with the longest cultivation history (from the 1950s and 1960s), yields have been estimated to be approximately $0.45-0.65$ tons/ha (2-3 bags/ acre). On the mid-foot slopes, typically fields allocated during the villagization process (1974-76), the estimated yield was 0.9-1.1 tons/ha (4-5 bags/acre). Finally, on the seasonally flooded and sometimes drained lowlands, dominated by newly bought or hired fields, yields were approximately $1.5-1.8$ tons/ha (7-8 bags/acre). The first two locations are most frequently used by peasant-laborers. 
Table 4

Land Access and Livelihood Strategies

\begin{tabular}{lcccc}
\hline \hline Accumulating farmers & $\begin{array}{c}\text { Cultivated Land } \\
\text { (Hectares) }\end{array}$ & $\begin{array}{c}\text { Uncultivated Land } \\
\text { (Hectares) }\end{array}$ & $\begin{array}{c}\text { Borrowed or Rented } \\
\text { Land }(\%)\end{array}$ & $\begin{array}{c}\text { Purchased Land } \\
(\%)\end{array}$ \\
\hline $\begin{array}{c}\text { Peasant-laborers } \\
(N=10)\end{array}$ & 2.27 & 0.41 & 10 & 30 \\
$\begin{array}{c}\text { Peasants } \\
(N=11)\end{array}$ & 2.27 & 0.57 & 54 & 9 \\
$\begin{array}{c}\text { Accumulating farmers } \\
(N=12)^{\mathrm{a}}\end{array}$ & 4.62 & 1.22 & 61 & 46 \\
\hline
\end{tabular}

Source: Village survey (1995).

${ }^{\text {a }}$ One farmer has been left out of this analysis, as he owned 171 hectares of land that were fallow.

capital allowing households to invest in tomato production (to buy fertilizer, pesticides, and land of good quality), trade, or other accumulating ventures. While village land use in general has intensified, it has happened more through expansion of the cultivated land than through intensification at the farm level.

\section{Discussion and Conclusions}

\section{Contextual Change and Its Impact on Livelihood and Land Use}

Livelihood opportunities and use of natural resources in Ikuwala were influenced by external factors throughout the period. A combination of constraints on pastoral production (cattle diseases) and increased market opportunities (infrastructure development and a market demand for food crops) favorably influenced a process of agrarianization in Mazombe (i.e., a process in which agricultural production increasingly came to dominate income strategies). This process was subsequently coupled with a process of commercialization, sustained by the adoption of technological innovation (expansion of fields through animal traction) and increased market opportunities for crops with a local production potential (maize, tomatoes, sunflower) and for charcoal, which is mostly produced illegally. Iringa villages are sometimes referred to as subsistence villages (e.g., Lulandala 1994), but this concept is hardly applicable in Ikuwala, given that farmers here operate with three major cash crops and sell even minor crops like cowpeas and finger millet. With commercialization, a process of economic growth and social differentiation took place. Generally, Ikuwala has become a more wealthy village, but in all likelihood (no baseline data exist) with a growing number of peasant-laborers-paupers-among its households.

These changes, in combination with the villagization settlement pattern, influenced natural resource management in several important ways. The area under cultivation has expanded throughout the period, and fallow areas have been reduced. Because of the villagization policies, production was concentrated on the flatter areas around the new nucleus settlement, but it later moved back to the hill plateaus. Meanwhile, increasingly new potentials (heavy and fertile soils) were explored as technological adoption took place. The vegetation cover has been characterized by oscillation dependent on how agricultural and grazing potentials were realized. A general decrease in land cover, including deforestation of hillslopes, has been a fact since the end of the 1970s, followed by both reactivation and formation of new gullies, sheet erosion, and increased flood incidence in the nucleus settlement. Thus, the development of relatively scarce land has implied increased use of marginal and risk-prone land. 


\section{Differential Access to and Use of Natural Resources}

The study has identified a variety of strategies in relation to access to and use and management of natural resources. These strategies are related to the differences in natural resource potentials. These potentials result, as we have shown, from the spatial location and production history of the resources in question. Historically, one way in which economic growth has taken place in Ikuwala is by moving the agricultural frontier. This process continues at present, in the sense that new areas are still drawn into cultivation in the hills and along the swamp. Moreover, it is still possible to rent relatively fertile land in nearby villages. The accumulating farmers thus have the option of renting out fields that are exhausted from long periods of cultivation and to hire or buy land of better quality. They have access to hired labor and technology (oxen and plough), and they are in a position to take risks with tomato production, which provides high returns. They use commercial inputs but do not add manure to any great extent. Thus, accumulating farmers have a range of opportunities without needing to venture into illegal charcoal production, but they do not have a strong incentive to embark on conservation measures, as they can still obtain land with good production potential. Their maize cultivation is quite low, but still higher than the other groups. A number of factors could explain these differences in yields, among which are the accumulating farmers' more fertile soil and better access to labor.

In contrast, the peasant-laborers are in a coping situation. To the extent that they can borrow, hire, or buy small pieces of land to compensate for their exhausted plots, these new plots may be located far away, and they are not able to hire labor. Land along the foothills, used by the families before villagization, is increasingly claimed with reference to customary law, but cultivation of this land, along with more marginal plots along streams, gullies, or on steeper slopes, accelerates runoff and erosion. In general, land productivity for this group is extremely low, and practices of fertility management are almost absent. An increase in yields per land unit would make a difference, especially in terms of food security, but peasant-laborers do not command the means to embark independently on conservation or productivity-enhancing efforts.

The middle group — the peasants — use a variety of strategies for the utilization of natural resources. They undertake various measures of fertility management according to their access to resources (manure, labor parties, and small amounts of hired labor and chemical fertilizer). More than half of the group borrow or rent land. It was also in this group that farmers moved back into the hills as a strategy of "marketaversion," favoring access to more fertile soil and water rather than according priority to the market. Even this group is marked by low returns per hectare, and farmers within the group suffer some of the same constraints as the peasant-laborers in terms of land and labor access, albeit to a different degree.

The productivity of the exhausted land close to the settlement and of the newly cultivated clay soil near the swamp differed by at least a factor of 4 . Restoring fertility to reasonable levels on the land around the settlement would demand major soil conservation and nutrient management efforts, but within the respective households resources do not seem to be available and/or prioritized.

\section{Livelihood, Income Strategies, and Land Degradation}

The livelihood approach provides a methodological framework for understanding, for example, how natural resource management integrates with management of other resources in a process of structural diversification. In Ikuwala, it became clear that livelihood diversification to an important degree takes place within the agricultural sector and with a strong rural core. 
What emerges from the examples above is the relatively modest monetary importance of noncrop incomes in comparison with crop incomes. For all livelihood categories, the agricultural economy has thus evolved as the most important sector in Ikuwala, to which other income opportunities relate. This is also underscored by the importance given to agricultural factors in the choice of wealth indicators. In Ikuwala, income diversification among the poorest groups is a means of remaining in control of land.

All livelihood groups were keen to hold on to their lands and to their positions as farmers. The income obtained from both agricultural and nonagricultural sources provides good reasons for this priority, as indicated in the case material. The accumulating households thus embarked on nonagricultural income sources such as crafts, businesses, or rents to expand their level of agricultural production and possibly also to obtain new land. The peasant group concentrated nonagricultural earnings in crafts and piecework, but incomes from these sources were mostly at a level that could only supplement the agricultural earnings. In the peasant-laborer group, monetary income from nonagricultural sources such as piecework, natural products sales, or beer brewing often surpassed that from agriculture, but agricultural production was nevertheless considered the main income source for food security reasons and for supplying grain for beer brewing. Among the two latter groups, livelihood diversification seemed more defensive than offensive-that is, it seemed a component in maintaining living standards rather than in changing themand for the peasant-laborers livelihood diversification was to a considerable degree conditioned by external demand.

The production and marketing of maize, tomatoes, and, more recently, the growing demand for sunflower as a result of the establishment of a new oil mill in Iringa implies that even peasant households in Ikuwala have managed to increase their incomes during a period when natural resources have been degraded. Thus, it seems that the main avenues for obtaining wealth are agricultural, either by developing tomato production or through the control of more or new land. Conservation of land belongs neither to the strategies of accumulation nor of survival.

The losers in this process were those households unable to benefit from new access to land or from tomato cultivation. Nearly one-third of the households in Ikuwala were impoverished and in no position to manage resources properly or to follow medium- or long-term strategies in order to change their lot. Even some members of the peasant group were in an insecure and vulnerable situation. However, poverty is hardly the main explanation for land degradation. The land that is most heavily degraded is or has been cultivated by the accumulating farmers as well as by other groups.

Intensification and degradation thus occur simultaneously. Even income growth among accumulating, and sometimes among peasant, households coincides with degradation. In this situation, the incentives to adopt conservation strategies seem insufficient.

\section{The Livelihood Approach}

From the foregoing discussion, it should be evident that the ways in which livelihood strategies relate to natural resource potentials at the subcommunity level are important in explaining agricultural and environmental change. The bottom-up perspective on resource endowment is one important advantage of a livelihood approach-here allowing the identification of various livelihood and management strategies within a framework of local issues. Studies of livelihood strategies take as axiomatic the heterogeneity of local farming and other income-generating practices, thereby allowing the possibility of uncovering diversified and possibly contradictory strategies with respect to resource management and maintenance.

So far, however, there is no common approach to the application of livelihood 
strategies. The one applied here has been developed while working on the data, and our purpose has not been to present a blueprint, but rather to present one possible way in which the approach can be applied. The approach is thus susceptible to different interpretations, and this can make generalizations and comparisons regarding regions difficult. Further methodological development is warranted, and based on our experience two issues are of particular importance.

First, heterogeneity is addressed differently in various livelihood studies. The way in which it has been addressed here, by establishing fairly rigid livelihood groups, carries the risk of homogenizing and essentializing resource management practices that should be treated in a less rigid fashion. On the other hand, we would argue that the groups identified in Ikuwala come close to capturing important management practices in the area. Second, the question remains of what is at the core of the livelihood approach. We would argue that the livelihood approach seeks to elaborate on more than just income strategies. It seeks to gain an understanding of resource access, use, and allocation and on the way in which individuals and householders transform resources into livelihoods. However, while this may be seen as the core of the approach, it also problematizes the context and the opportunities to which householders and individuals respond. The approach therefore represents an opportunity for gaining a more systematic approach to bottom-up studies and the interfaces between actors and structure.

\section{References}

Adams, W. M., and Mortimore, M. J. 1997. Agricultural intensification and flexibility in the Nigerian Sahel. Geographical Journal 163:150-60.

Aune, J. B. 1997. Structural adjustment and soil degradation in Tanzania. Discussion Papers 189, Statistics Norway. Ås: Norwegian University of Agricultural Science.

Bagachwa, M. S. D., and Limbu, F., eds. 1995. Policy reform and the environment in
Tanzania. Dar es Salaam: Dar es Salaam University Press.

Bebbington, A. 1999. Capitals and capabilities: A framework for peasant viability, rural livelihoods and poverty. World Development 27:2021-45.

Birch-Thomsen, T. 1993. Effects of land-use intensification-Introduction of animal traction into farming systems of different intensities. Geografica Hafniensia A2 (Publications-Institute of Geography, University of Copenhagen).

1996. Environment, people and land use. SASA Notes and Working Papers, May 1996. Centre for Research on Sustainable Agriculture in Semi-Arid Africa, Copenhagen and Roskilde.

Birch-Thomsen, T., and Frederiksen, P. 1995. Report on fieldwork in Iringa District, Tanzania. SASA Notes and Working Papers, January 1995. Centre for Research on Sustainable Agriculture in Semi-Arid Africa, Copenhagen and Roskilde.

Blaikie, P. 1985. The political economy of soil erosion in developing countries. New York: Longman.

Blaikie, P., and Brookfield, H., eds. 1987. Land degradation and society. New York: Methuen.

Boesen, J., and Ravnborg, H. M. 1992. Peasant production in Iringa District, Tanzania. CDR Project Paper 93.1. Copenhagen: Centre for Development Research.

Branner-Jespersen, C. 1971. Southern highlands socio-economic study. Final report. Uyole Agricultural Research Station, Mbeya.

Bryceson, D. F. 1999. African rural labour, income diversification and livelihood approaches: A long-term development perspective. Review of African Political Economy 80:171-89.

Campbell, B. 1996. The miombo in transition: Woodlands and welfare in Africa. Center for International Forestry Research (CIFOR), Bogor, Indonesia.

Carney, D., ed. 1998. Sustainable rural livelihoods: What contributions can we make? London: Department for International Development.

Christiansson, C.; Dahlberg, A.; Loiske, M.-V.; and Östberg, W., eds. 1993. Environmentusers-scholars: Exploring interfaces. Stockholm: EDSU, School of Geography, Stockholm University.

Dahlberg, A. 1994. Contesting views and changing paradigms. The land degradation debate 
in Southern Africa. Discussion Paper No. 6. Uppsala: Nordiska Afrikainstitutet.

Davies, S. 1996. Adaptable livelihoods. Coping with food insecurity in the Malian Sahel. Chichester: Wiley.

Ellis, F. 1998. Household strategies and rural livelihood diversification. Journal of Development Studies 35 (1):1-38.

Ellis, J. E., and Swift, D. M. 1988. Stability of African pastoral ecosystems: Alternate paradigms and implication for development. Journal of Range Management 41:450-59.

European Economic Commission (EEC). 1986. Regional agricultural development plan, Iringa Region, final report. Joint report of the United Republic of Tanzania and the European Development Fund. Essen, Germany: Agrar-und-Hydrotechnik GMBH.

Fairhead, J., and Leach, M. 1996. Misreading the African landscape: Society and ecology in a forest-savanna mosaic. Cambridge: Cambridge University Press.

Feldman, R. 1983. Ismani: Agricultural change and the politics of ujamaa. Monographs in Development Studies No. 10. Norwich: School of Development Studies, University of East Anglia.

Francis, E. 1998. Gender and rural livelihoods in Kenya. Journal of Development Studies 35 (2):72-95.

Frederiksen, P. 1998. Environmental changea case study from Ikuwala. Paper presented at workshop on "Land Use Intensification in Semi-arid Iringa-Its Causes, Forms and Consequences," 6 October, in Iringa, Tanzania, organized by Centre for Research on Sustainable Agriculture in Semi-arid Africa (SASA).

Joekes, S.; Heyzer, N.; Oniang'o, R.; and Salles, V. 1994. Gender, environment and population. In Development and environment: Sustaining people and nature, ed. D. Ghai, 137-65. Oxford: Blackwell/UNRISD.

Kikula, I. S. 1997. Policy implications on environment-The case of villagization in Tanzania. Uppsala, Sweden: Nordic Africa Institute.

Kiwasila, H., and Odgaard, R. 1992. Socio-cultural aspects of forest management in the Udzungwa. Report prepared for Danida. Copenhagen: Centre for Development Research.

Little, P. D. 1994. The social context of land degradation ("desertification") in dry regions. In Population and environment-Rethinking the debate, ed. L. Arizpe, M. P. Stone, and D. C. Major, 209-51. Oxford: Westview Press.
Loiske, M.-V. 1995. The village that vanishedthe roots of erosion in a Tanzanian village. Meddelanden Series B 94. Department of Human Geography, Stockholm University.

Lulandala, G. D. 1994. Analysis of factors affecting agricultural productivity in selected subsistence farming villages in Tanzania. Ph.D. diss., University of Michigan, Ann Arbor.

McIntire, J.; Bourzat, D.; and Pingali, P. 1992. Crop-livestock interaction in sub-Saharan Africa. World Bank Regional and Sectoral Studies. Washington, D.C.: World Bank.

Mortimore, M. 1995. Caring for the soil: Agricultural expansion, population growth, and natural resource degradation in the Sahel. In The Sahel-Ethnobotany, agricultural and pastoral strategies, development aid strategies, ed. A. Reenberg and H. Secher Marcussen. Proceedings of the 7th Danish Sahel Workshop, 4-6 January 1995. SahelSudan Environmental Research Initiative (SEREIN) Occasional Paper No. 1. Copenhagen.

Mung'ong'o, C. G. 1995. Social processes and ecology in the Kondoa Irangi Hills, central Tanzania. Ph.D. diss., Department of Human Geography, Stockholm University.

Murton, J. 1997. Sustainable livelihoods in marginal African environments? The social and economic impacts of agricultural intensification in Makueni District, Kenya. Paper presented to the ESRC Conference on Sustainable Livelihoods in Marginal African Environments, Sheffield University, 10-11 April.

Ndangalasi, H. 1998. Off-field vegetation study_Ikuwala, Mkulula, Ilambilole and Kalenga Villages, Iringa Rural District, Tanzania. SASA Notes and Working Papers, October 1998. Centre for Research on Sustainable Agriculture in Semi-Arid Africa, Copenhagen and Roskilde.

Netting, R. McC. 1993. Smallholders, householders-Farm families and the ecology of intensive, sustainable agriculture. Stanford: Stanford University Press.

Preston, D. 1992. Households and the analysis of their livelihood strategies. Working Paper 92(11). School of Geography, University of Leeds.

Raikes, P. 1986. Eating the carrot and wielding the stick: The agricultural sector in Tanzania. In Tanzania: Crisis and struggle for survival, ed. J. Boesen, K. Havnevik, J. Koponen, and R. Odgaard, 105-41. Uppsala: Scandinavian Institute of African Studies. 
Rasmussen, T. 1986. The Green Revolution in the Southern Highlands. In Tanzania: Crisis and struggle for survival, ed. J. Boesen, K. Havnevik, J. Koponen, and R. Odgaard, 191-205. Uppsala: Scandinavian Institute of African Studies.

Reardon, T. 1997. Using evidence of household income diversification to inform study of the rural non-farm labour market in Africa. World Development 25:735-47.

Reardon, T., and Vosti, S. A. 1995. Links between rural poverty and the environment in developing countries: Asset categories and investment poverty. World Development 23:1495-1507.

Reed, D., ed. 1996. Structural adjustment, the environment, and sustainable development. London: Earthscan.

Reitsma, H.; Dietz, T.; and de Haan, L., eds. 1992. Coping with semi-aridity: How rural poor survive in dry-season environments. Amsterdam: University of Amsterdam.

Ruthenberg, H. 1980. Farming systems in the tropics. 3d ed. Oxford: Oxford University Press.

Sano, H.-O. 1999. Enabling strategies and state intervention: Major Livelihood problems in semi-arid villages in Iringa District, Tanzania. In Sustainable agriculture in semiarid Tanzania, ed. J. Boesen, I. Kikula, and F. Maganga. Dar es Salaam: Dar es Salaam University Press.

Scoones, I. 1997. The dynamics of soil fertility change: Historical perspectives on environmental transformation from Zimbabwe. Geographical Journal 163:161-69.

_. 1998. Sustainable rural livelihoods: A framework for analysis. IDS Working Paper 72. Brighton, Institute of Development Studies.

Secher Marcussen, H., ed. 1993. Institutional issues in natural resources management. Occasional Paper No. 9. International Development Studies, University of Roskilde.

Tanzania Rural Development Bank (TRDB). 1976. Iringa Region, Tanzania. Integrated rural development proposals for the third five-year plan, 1976-81. Prepared by Overseas Development Group, University of East Anglia. Dar es Salaam: UNDP and FAO.
Thomas, D. S. G., and Middleton, N. J. 1994 Desertification: Exploding the myth. Chichester: John Wiley.

Thomson, J. T. 1994. The role of the state versus the community in governance and management of renewable natural resources. An argument and Sahelian examples. Occasional Paper no. 12. International Development Studies, University of Roskilde.

Tiffen, M.; Mortimore, M.; and Gichuki, F. 1994. More people less erosionEnvironmental recovery in Kenya. Chichester: John Wiley.

United Nations Development Programme (UNDP). 1999. Sustainable livelihoods. http://www.undp.org/sl/.

United Republic of Tanzania. 1969. 1967 population census, vol. 1, Statistics for enumeration areas. Dar es Salaam.

—_ 1978. 1978 population census. Preliminary report. Dar es Salaam.

- 1988. Bureau of Statistics: Tanzania Sensa 1988, Preliminary. Dar es Salaam.

Östberg, V. 1995. Land is coming up: The Burunge of central Tanzania and their environments. Stockholm: Stockholm Studies in Social Anthropology.

Øygård, R. 1997. Structural adjustment policies and land degradation in Tanzania. Forum for Development Studies, No. 1. Oslo.

\section{Images}

United Republic of Tanzania. Department of Surveys and Mapping. 1955-56. Aerial photographs (Re 1912.112-14). Dar es Salaam.

— - 1977-78. Aerial photographs (Re 1842_02-04). Dar es Salaam.

1:50,000 map of Tanzania. Series Y742, sheet 215/2 and 216/1, edition 1-TSO.

U.S. Geological Survey. 1966. Declassified Corono Satellite Photograph (B/W), November (DS 1037-2154DF023). EROS Data Center, Sioux Falls.

Système Probatoire d'Observation de la Terre (SPOT). 1986. SPOT-HRV. Scene id. 140/366 XS 860812; Band 1, 2, 3.

Landsat Thematic Mapper (TM). 1993. Scene id. 168-0-065 931210; Band 2, 3, 4.

. 1996. Scene id. 168-0-065 960828; Band 2, 3, 4 . 